\title{
Gestational Trophoblastic Tumor Pathologic Primary Tumor TNM Finding v7
}

National Cancer Institute

\section{Source}

National Cancer Institute. Gestational Trophoblastic Tumor Pathologic Primary Tumor

TNM Finding v7. NCI Thesaurus. Code C89695.

A pathologic finding about one or more characteristics of gestational trophoblastic

tumor, following the rules of the TNM AJCC V7 classification system as they pertain to staging of the primary tumor. 